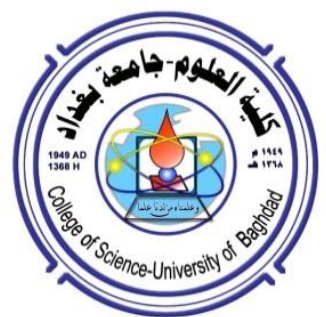

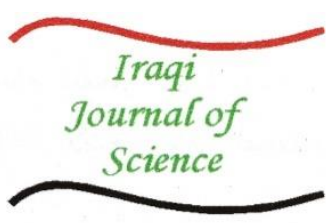

ISSN: 0067-2904

\title{
Heat Treatments Effects on the Fatigue Behaviors of Aluminum Nano- Composite Alloys
}

\author{
Mamoon A. A. Al- Jaafari \\ Mechanical Eng. Department, University of Al-Mustansiriya, Baghdad, Iraq
}

Received: $17 / 1 / 2021$

Accepted: $12 / 7 / 2021$

\begin{abstract}
The fatigue is one of the major reasons for fracture of materials. Aluminum 7204 AA alloy with various heat treatments and (2.0) wt \% of $\mathrm{SiC}$ nanoparticles were prepared by stir-casting method under rotating bending loading with ratio of stress $(\mathbf{R}=-1)$. The composite was strengthened by $\mathrm{SiC}$ particles size of( 10 )nanometre. The fatigue strength and life were obtained experimentally by the family of S-N curves for different heat treatments. The endurance limits $\left(\mathbf{1 0}^{7}\right.$ cycles $)$ for 7204 AA/ $2.0 \mathrm{wt} \% \mathrm{SiC}$ nano-composite fatigue strength as related to untreated nanocomposite was enhanced by 72 and $78.5 \%$ for T4 and T6, respectively.The improvement of fatigue properties is due to better spreading of $\mathrm{SiC}$ nanoparticles and increased porosity.
\end{abstract}

Keywords: Nanotechnology, Nano composite, aluminum alloy, high-cycle fatigue, $\mathrm{SiC}$.

تأثير المعالجات الحرارية على سلوكيات أجهادالكلال لسبائك الألومنيوم المركبَة النانوية

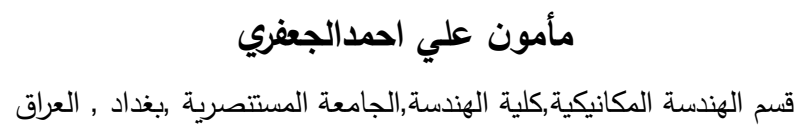

الخلاصة

يعتبر اجهاد الكلال هو أحد الأسباب الرئيسية لكسر المواد .ان سبائك الألومنيوم AA 7204 ذات معالجات حرارية مختلفة و الجسيمات النانوية من كاربيد السيكون(2.0) ٪ثنبة وزنية وتم تصنيع العينات

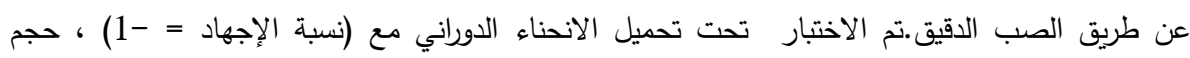
جزيئات كاربيد السيلكون=10 نانومتر • تم الحصول على قوة إجهاد وعمر الكلال بثكل تجريبي باستخدام

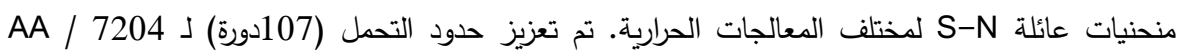
SiC nano-composite Strength \%2.0wt قبل لـ T6 و T6 على التوالي .تحسن الخواص قد اتى من الانتثار الأفضل لجزيئات SiC النانوية ، وكنلك لفاني

$$
\text { زيادة المسامية }
$$

\section{Introduction}

Aluminium metal is a white to sliver metal whicrepresents about $8 \%$ of the earth's crust. It is of very light weight, its specific weight is $2.7 \mathrm{gr} / \mathrm{cm}^{3}$ which is equivalent to one third of iron 
specific weight, which is good conductivity for heat and electricity, as it is Two-thirds of the copper-conductor is copper, but it is a low-strength mineral of less than $50 \mathrm{HB}$. Its resistance to tensile is no more than $290 \mathrm{~N} / \mathrm{mm}$, which is why it is used in alloy for most of its applications. The basic elements that are added to aluminium to form the alloy are : Copper, Magnesium, Manganese, Silicon and Zinc [1-3]. When heat-treatable aluminium alloys were endangered to aging process the insistence of the enunciation to release its crystal structure and raising the mechanical properties. Aging from lytic treatment solution treatment, at free temperatures introduces a high degree of disintegration which is the dissolution of all elements in the phase of aluminum beds and then sudden cooling to room temperature (paper bed) to drop into solution stented solid where you dash the elements precipitated later during the heat treatment of aging. Aging of the aluminum alloys bed begins to kicking areas Guinier - Preston (GP zones) they are solutions rich in dissolved atoms spread out shark contract coherent clusters (CC) which distorts the crystal lattice structure. These nodes resist the movement of dislocations within the crystal lattice, which leads to a cessation or slowdown in the synthesis or growth of fissures. Increase the strength and durability of the metal [4-8].

Wang et al. investigated and compared heat treatment effects on improving the inter-granular corrosion (IGC) strength of aluminum nanocomposite alloys to the T6 temperature. The twostep aging treatment consists of pre-aging at comparatively high temperature for a short time and then re-aging at lower temperature for comparatively extended period of time. The microstructural inspection displayed that after the adjusted aging of $180{ }^{\circ} \mathrm{C} / 2 \mathrm{~h}+160{ }^{\circ} \mathrm{C} / 120 \mathrm{~h}$, the sort of microstructures was s accountable for the enhancement of resistance of the alloy unaccompanied by strength lack [9].

Cao et al. started to create a rapid aging effect on the cracking of the serrate with the composition the rapid aging of the applied layer which resulted in more phase density (Al, $32 \mathrm{~T} \mathrm{Mg} 49 \mathrm{Zn}$ ) and the softness of its granules, as it was transformed from the orthogonal polycarbonate to coarse oxide. Smoother coil, also resulted in the $\mathrm{MgCu} 2 \mathrm{Al}-\mathrm{S}$ acupuncture phase decay. There was an increase in coercion, from (199) Vickers hardness to (120) Vickers hardness [10].

Al-alkawi et al. . investigated $2014 \mathrm{AA}$ with $\mathrm{Al}_{2} \mathrm{O}_{3}$ nanoparticles reinforcement.The results showed that the addition of $\mathrm{Al}_{2} \mathrm{O}_{3}$ nanoparticles improved the Brinlle hardness, ultimate tensile stress and yield stress of $2014 \mathrm{AA}$. The analyses of inspection showed that the highest improvement was detected at 0.4 wt. $\% \mathrm{Al}_{2} \mathrm{O}_{3}$. The ultimate enhancement ratio was $15.78 \%$ BHN, $18.1 \%$ ultimate tensile stress, and $12.86 \%$ yield stress [11].

Schubert and Nestler investigated the SiC nano particles with $25 \%$ vol. that strengthened aluminium alloy AA2124. These are light-specific weight materials containing a relatively supple aluminum alloys and tough entrenched particles. The extreme hardness of the reinforcement led to superb abrasion resistance. The surface was predisposed by the geometry of the tool.The researchers labeled the effect of changed corner shape and the wear land. The results exhibited showed that the roughness of surface maybe fallen by wiper tools geometry [12].

Mishra et al. tested 7075 AA with SiC composite work-piece, lathed in dry and spray refrigeration condition based on L.16E Taguchi design of experiments. The performance features studied were roughness of surfaces, cutting tool temperature and rate of material removal .. Investigational results showed that lathing in cooling conditions was more advantageous than that in dry conditions for the quality. Analysis of variance exhibited that feeding was the most important parameter for the many implementation during lathing in both working conditions [13].

Das et al. examined. two sets of nine different SiC emphasized 7075 AA. Composites were made-up using stir casting method. One set as-cast without heat treatment, and the other one was heat treated to $\mathrm{T} 6$ condition. The production procedure limitations were then heightened 
using Taguchi based grey relational analysis. The main value was gotten by size $6 \mathrm{~nm}$ and 25 wt. \% SiC which resulted of $42 \%$ of enhancement in grey relational grade. The contribution effects of each procedure parameter considered complete analysis of variance [14].

Shijin et al. investigated by experimental and finite-element method the machinability of aluminum alloys with $\mathrm{SiC}$ of $25 \mathrm{vol} \%$. A more than single step cutting approach with depths of cut varying from 2 to $10 \mu \mathrm{m}$ was accepted to achieve a fundamental depth of cut of $10 \mu \mathrm{m}$ by aluminum /SiC.. Full estimates measured the similarity or dissimilarity between numerical simulation and actual results of diamond cutting tools of $\mathrm{Al} / \mathrm{SiC}$ nano-composite disclosed a considerable influence number step of the cutting. The results offered guidelines for reaching elevated finish of the surface of $\mathrm{Al} / \mathrm{SiC}$ composites [15].

Liu et al. studied silicon carbide effect brittleness property of (2024 AA 45 vol. $\% \mathrm{SiC}$ ) composites on machining. A different machining method was specially designed for this material to repress the shedded SiC particles.So, the shedded particles were decreased ,the resulted surface roughness was improved and the wear of tool is repressed considerably [16].

Huang et al. investigated the effects of silicon carbide strengthened aluminium ( $\mathrm{Al} / \mathrm{SiC}$ ) composites been milled at a high-velocity, the particle sizes were 5, 10, 25, and $32 \mathrm{~nm}$. The machined materials was (Aluminium /SiC) with the was $45 \%$ vol. and the size of SiC particles was $5 \mathrm{~nm}$., wear resistances of the tool get better results $4 \mathrm{~nm}$ particle sizes were all distant upper than these in machining composites with more volume fraction $(56 \%)$ and bigger $\mathrm{SiC}$ units [17] .

\section{Experimental work}

\subsection{Material}

\subsubsection{Base Metal}

The stand aluminums metal matrix employed in this is 7204AA aluminum. It is a part of $7 \mathrm{xxx}$ sequences of aluminum. the main alloying added element was zinc which was framed for initial establishing in formed products. The U.N.S no.is A/97204.It be given its standard specification in 2005, become a justly younger material. Table 1 shows the chemical composition of 7204 AA.

Table 1- The chemical composition of 7204 AA

\begin{tabular}{|c|c|}
\hline Element & $\begin{array}{c}\text { 7204 AA Standard } \\
{[18](\text { wt. \%) }}\end{array}$ \\
\hline$S i$ & 1.0 to 2.0 \\
\hline$Z n$ & 4.0 to 5.0 \\
\hline $\mathrm{Fe}$ & 0.2 to 0.7 \\
\hline$M g$ & 0 to 0.35 \\
\hline$M n$ & 0.2 to 0.7 \\
\hline$T i$ & 0to 0.2 \\
\hline $\mathrm{Cu}$ & 0.0 t0 0.2 \\
\hline$V$ & 0to 0.1 \\
\hline $\mathrm{Cr}$ & 0to 0.3 \\
\hline$Z r$ & 0 to 0.25 \\
\hline$\overline{A l}$ & Balance \\
\hline
\end{tabular}


The chemical composition of aluminum nano composite alloy was tested with an atomic fluorescence spectrometer (model A- fse 2000/2A). Table 2 shows some physical properties of both alloys of this work.

Table 2 - Show some physical properties of 6066AA and 7005AA alloys [18].

\begin{tabular}{|c|c|}
\hline Property & Value -SI units \\
\hline Density & $2.9 \mathrm{~g} / \mathrm{cm} 3$ \\
\hline Porosity & $0 \%$ \\
\hline Color & black \\
\hline Flexural Strength & $550 \mathrm{MPa}$ \\
\hline Elastic Modulus & 410GPa \\
\hline Shear Modulus & $\mathrm{GPa}$ \\
\hline Bulk Modulus & $\mathrm{GPa}$ \\
\hline Poisson's Ratio & 0.33 \\
\hline Compressive Strength & 3900MPa \\
\hline Hardness & $2800 \mathrm{Kg} / \mathrm{mm} 2$ \\
\hline Fracture Toughness K IC & 4.6MPa $\bullet \mathrm{m} 1 / 2$ \\
\hline Maximum Use Temperature & $1650^{\circ} \mathrm{C}$ \\
\hline Thermal Conductivity & $\left.120 \mathrm{~W} / \mathrm{m} \cdot{ }^{\circ} \mathrm{K} \cdot \mathrm{hr} \cdot{ }^{\circ} \mathrm{F}\right)$ \\
\hline Coefficient of Thermal Expansion & 4.0 at $10 /{ }^{\circ} \mathrm{C}$ \\
\hline
\end{tabular}

\subsubsection{Reinforcement Material}

Silicon carbide $(\mathrm{SiC})$ has been chosen as the nano particulate reinforcement. The particles size of $\mathrm{SiC}$ is extremely small size of (10) $\mathrm{nm}$ for fabrication aluminum nano composites. SiC has a strong bondage with aluminum metal so that made it is one of the best choices for alloys with $7 \mathrm{xxx}$ family for either strain hardening or heat treatments. Table 3 lists the major properties of $\mathrm{SiC}$ nano particle.

Table 3 - The major properties of Silicon Carbide nano particle.

\begin{tabular}{c|c}
\hline Property & Value $-\mathbf{S I}$ units \\
\hline Density & $3.1 \mathrm{gm} / \mathrm{Cm} 3$ \\
Porosity & $0 \%$ \\
Color & black \\
Flexural Strength & $550 \mathrm{MPa}$ \\
Elastic Modulus & $410 \mathrm{GPa}$ \\
Shear Modulus & $\mathrm{GPa}$ \\
Bulk Modulus & $\mathrm{GPa}$ \\
Poisson's Ratio & 0.14 \\
Compressive Strength & $3900 \mathrm{MPa}$ \\
Hardness & $2800 \mathrm{Kg} / \mathrm{mm} 2$ \\
Fracture Toughness K IC & $4.6 \mathrm{MPa} \bullet \mathrm{m} 0.5$ \\
Maximum Use Temperature & $1650^{\circ} \mathrm{C}$ \\
\hline Thermal Conductivity & $\mathbf{1 2 0} \mathbf{W} / \mathbf{m} \bullet \mathbf{K}$ \\
\hline
\end{tabular}




\subsection{Preparation Method}

At the time of aluminum matrix-alloys preparation, the duly cleaned matrix alloy was preheated with purified water or any cleaning material at a maximum temperature of $450^{\circ} \mathrm{C}$ to deoxidize it.The temperature was, thereafter, increased to melt the base metal matrix and was stirred for $10-15 \mathrm{~min}$. After that the $200^{\circ} \mathrm{C}$ preheated $\mathrm{SiC}$ was added to the molten aluminum, some appropriate dampening agent of vital weight was added and the mixture was blended carefully with an electrical mixer for $20 \mathrm{~min}$, , the harsh slurry is moved to steel mold $[19,20]$.

The prepared material was aluminum alloy 7204 / 2.0wt. \%Sic nano composite. It was prepared by the stir casting method. 20 test samples were used as cast without any heat treatment . 20 test samples were solution treated, at a temperature of $558^{\circ} \mathrm{C}$ for one hour, quenched in water, and left at room temperature for aging (T4 treatment), 20 other test samples ( T6 treatment) were prepared at different temperatures and periods of time. The age hardening reaction of the composite using fatigue behaviors was described by Rajasekaran [21]. The dimensions of specimens ASTM E8/E8M are primarily used for metallic materials. In this model, the cross-sectional area at the center of the sample was the smallest to ensure that fracture occurs within the gauge length. The shape of this model is shown in Figure 1. It has a long grip area so that the overall specimen length is relatively long. The tensile test specimen dimension according to the standard is listed in Table 5 [19].

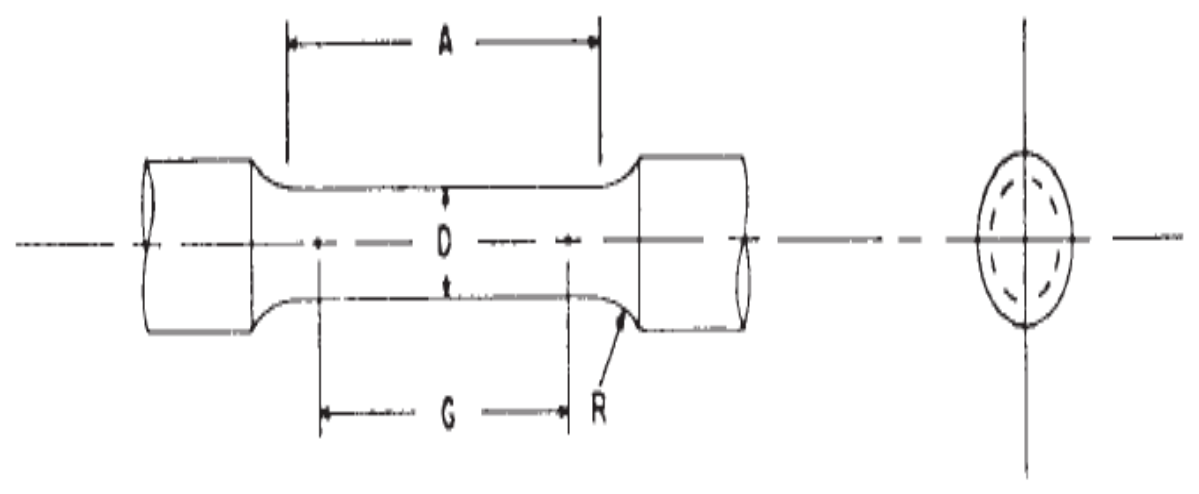

Figure 1- Tensile test specimen shape

Table 4 - The Tensile test specimen dimension.

\begin{tabular}{llc}
\hline & \multicolumn{2}{c}{ Dimensions, mm } \\
\cline { 2 - 3 } & \multicolumn{2}{c}{ Standard Specimen } \\
\hline G-Gage length & $62.5 \pm 0.1$ & 9 \\
D-Diameter (Note 1) & $12.5 \pm 0.2$ & $45.0 \pm 0.1$ \\
R-Radius of fillet, min & 10 & $9.0 \pm 0.1$ \\
A-Length of reduced section, min (Note 2) & 75 & 8 \\
\hline
\end{tabular}

The fatigue specimen dimensions are given in Figure 2, the shape and the dimensions were according to ISO 1143. 


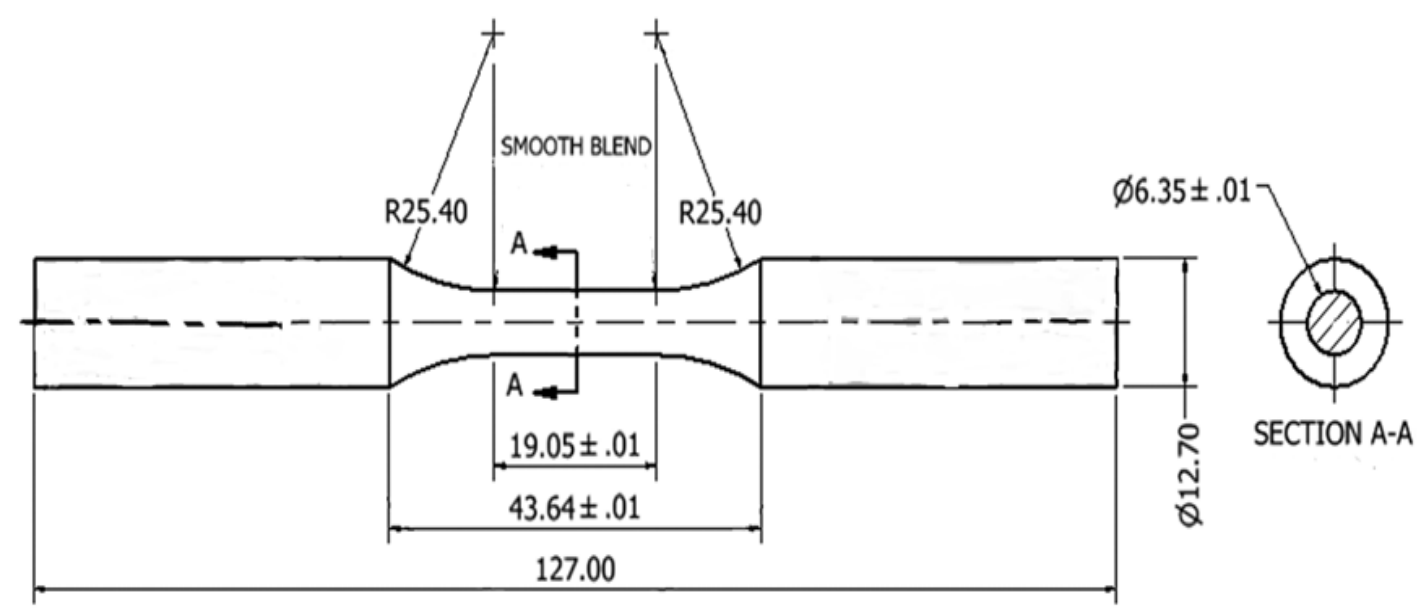

Fatigue Specimen - $(\mathrm{mm})$

Figure 2-Fatigue test specimen dimensions [19]

\section{Results and Discussion}

\subsection{Tensile Test}

Tensile test was implemented on universal testers' which support the framework extension at discontinuity, to be deliberate well with the rate of extension mutable rendering to the test technique and a supplies. Test approaches ASTM E-8/E-8M.

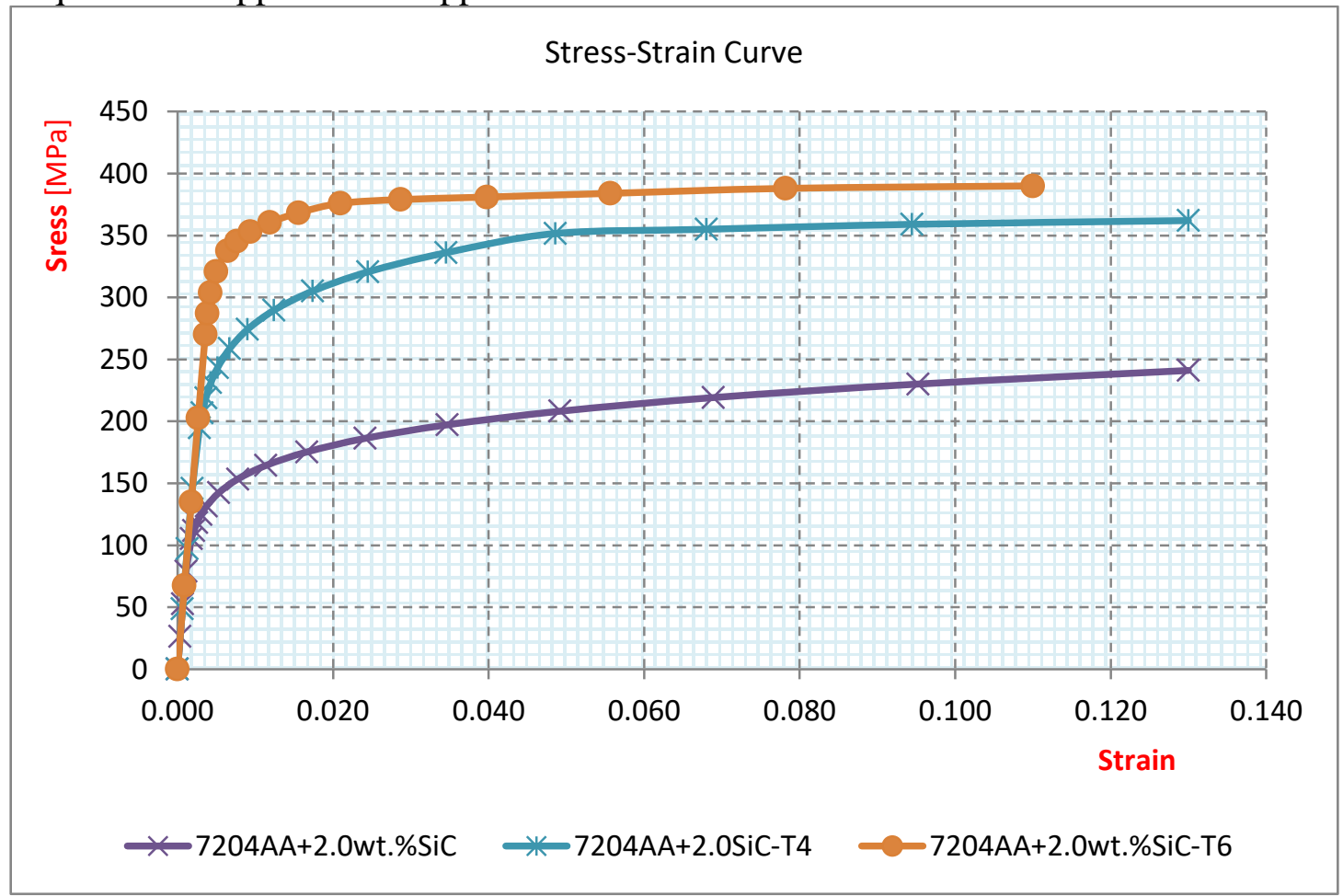

Figure 3- stresses -strain curve for different heat treatment of Aluminum Alloy

Table 5-The Ultimate Tensile Strength and percentage Improvements

\begin{tabular}{|c|c|c|c|}
\hline Treatment & $\begin{array}{c}\text { Ultimate Tensile Stress } \\
\text { (MPa) }\end{array}$ & Change in $\sigma$ en. \% & Yield Stress (MPa) \\
\hline Untreated & 230 & --- & 125 \\
\hline T4 treatment & 362 & 57.39 & 230 \\
\hline T6 treatment & 389 & 69.13 & 340 \\
\hline
\end{tabular}




\subsection{Fatigue Test}

Constant amplitude fatigue tests by rotating with bending fatigue testing instrument Schencke brand KFG-8 was utilized. The fatigue specimens have circular cross sections and are subjected to different loads perpendicular to their vertical axis a form the right side. This load initiates a bending-moment. Thus, specimen's inner and outer surface would be in tensile and compression stresses, correspondingly it will start rotating. The value of the applied load to the sample for an established amount of stress $(\sigma)$, in units of (MPa), was calculated by applying the relationship: $\sigma=(32 * 125.7 * P) /\left(\pi * d^{3}\right)$ Where $(\mathrm{d})$ is specimen diameter in $(\mathrm{mm})(\mathrm{P})$ is load in $(\mathrm{N})$, the arm of the force is $(125.71 \mathrm{~mm})$, and stress $(\sigma)$ in $\left(\mathrm{KN} / \mathrm{mm}^{2}\right)$ [22]. The samples were established in stable amplitude fatigue stress, at $28^{0} \mathrm{C}$, to approximation the $\boldsymbol{S}-\boldsymbol{N}$ curve. The results are tabulated in in Table.6.

Table 6 The Fatigue parameters for various heat treatments.

\begin{tabular}{|c|c|c|c|c|c|c|}
\hline Treatment & $\alpha$ & $\beta$ & Equation & $\begin{array}{c}\text { Stress at } \\
1^{7}\end{array}$ & $\begin{array}{c}\text { Changed } \\
\text { in oe }\end{array}$ & $\mathbf{r}^{2}$ \\
\hline Un treated & 449.931 & 0.111 & $\sigma \mathrm{f}=449.931 \mathrm{Nf}^{-0.111}$ & 75.187 & --- & 0.98 \\
\hline T4 treatment & 464.741 & 0.111 & $\sigma \mathrm{f}=736.251 \mathrm{Nf}^{-0.111}$ & 129.869 & $+72.05 \%$ & 0.98 \\
\hline T6 treatment & 782.541 & 0.112 & $\sigma \mathrm{f}=782.541 \mathrm{Nf}^{-0.112}$ & 134.251 & $+78.56 \%$ & 0.98 \\
\hline
\end{tabular}

The ( S-N) curves ,for the7204 AA and $7204 \mathrm{AA} / \mathrm{SiC}$ nano-composite, of related stress vs no. of cycles to failure are shown in Figure 4. It must be minutes that the stresses is the utilized until fail $\left(\sigma_{\mathrm{f}}\right)$. The shape is congruous for $(\mathrm{S}-\mathrm{N})$ curves. 120 samples have been test to obtain these (S-N) curves, 60 samples as received 7204 AA Alloy ,60 samples with (2.0) nm size of $\mathrm{SiC}$ reinforcement .The (S-N) curves equations the samples are exhibited in Table (6). (S$\mathrm{N})$ curves equations were intended by Basquin law in the configuration $\left(\sigma_{f}=\boldsymbol{\alpha} N_{f}^{\beta}\right)$ where; $\boldsymbol{\alpha}$ and $\boldsymbol{\beta}$ are constant of the material under study. The equations are the curve fitting equations of the investigational data of the fatigue tests. The constants $\alpha$ and $\beta$ and the correlation coefficient $\left(\mathbf{\Upsilon}^{2}\right)$ are listed in Table(6). The S-N curve equation has well $\left(\boldsymbol{\Upsilon}^{2}\right)$ which demonstrates that the investigational data well describes Basquin equation.

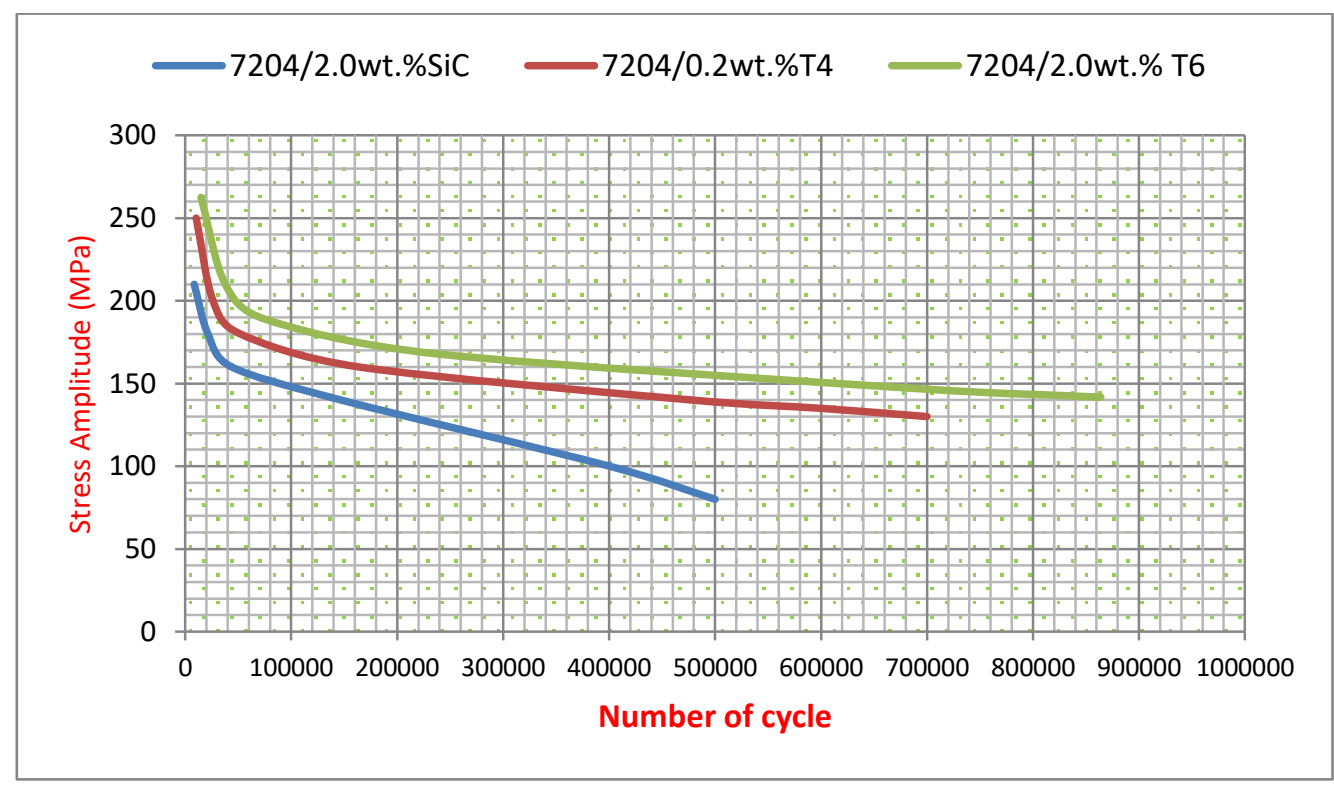

Figure 4-Stress vs. number of cycle curves for various heat treatments. 
The fatigue endurance strength or fatigue endurance limit $\left(\sigma_{\mathrm{EL}}\right)$ for 6061-Al alloy was 30.12 $\mathrm{MPa}$ and $12.78 \mathrm{MPa}$ for $10^{7}$ and $5 * 10^{8}$ cycles, respectively . As the $\mathrm{N}$ nanocomposite was by $11.48 \%$ to $11.05 \% \%$ i-e the maximum improvement in $\left(\sigma_{\mathrm{EL}}\right)$ occurred at $2.0 \mathrm{wt} \% \mathrm{SiC}$, i-e the $\left(\sigma_{\mathrm{EL}}\right)$ enhanced from $30.12 \mathrm{MPa}$ to $33.58 \mathrm{MPa}$. The enhancement of $\left(\sigma_{\mathrm{EL}}\right)$ is illustrated in Figure 5.

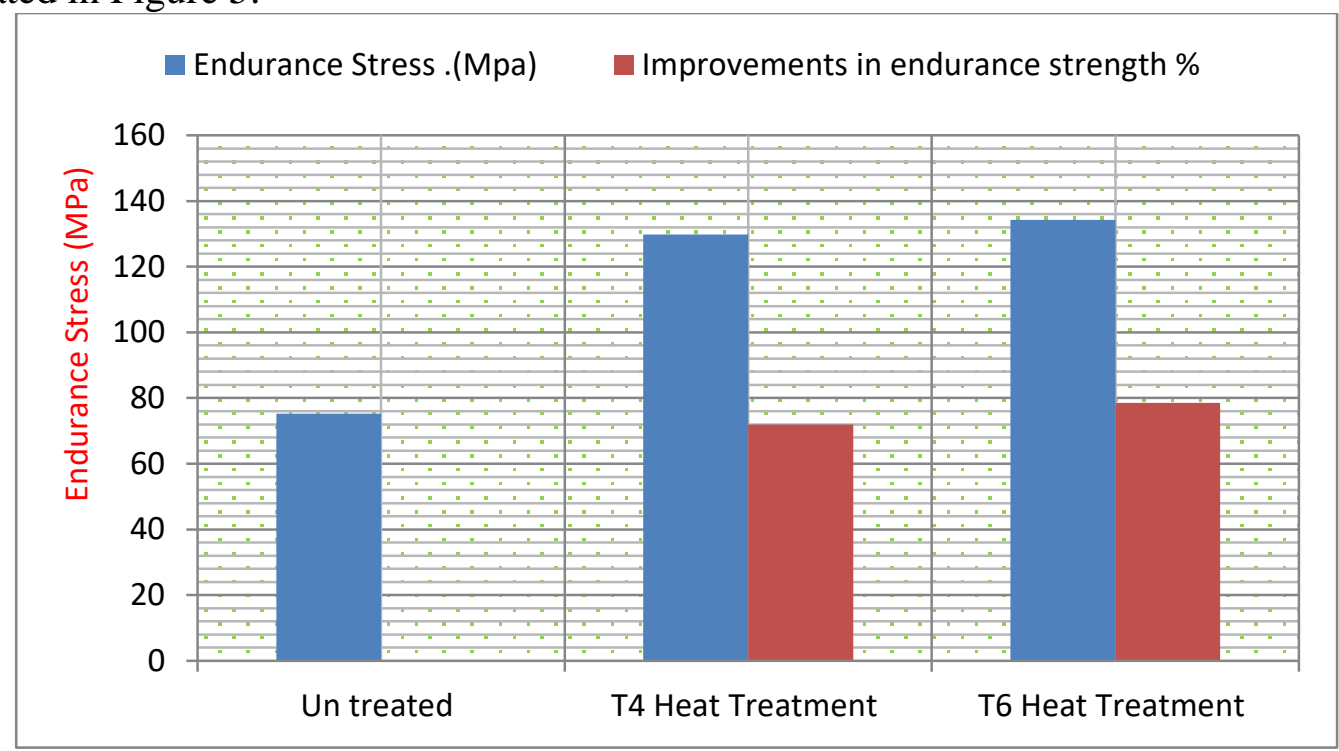

Figure 5-Endurance strength and improvement in endurance strength for different types of heat treatment for 7204-SiC Aluminum nanocomposite

\section{Conclusion}

The main conclusions from this experimental investigation are:

1. The addition of $2.0 \mathrm{wt}$. $\%$ of $\mathrm{SiC}$ nano particles to $7204 \mathrm{AA}$ to produced nano composite material, increased the ultimate tensile stress by $57.39 \%$, for T4 Treatment and by $69.13 \%$ for that of T6 treatment.

2. The endurance limit (at $10^{7}$ cycles) for $7204 \mathrm{AA} / 2.0 \mathrm{wt} \% \mathrm{SiC}$ nano-composite fatigue strength as compared with the value of the untreated nanocomposite was enhanced by $72 \%$ and $78.5 \%$ for $\mathrm{T} 4$ and $\mathrm{T} 6$, respectively.

3. The enhancements of aluminum nanocomposite properties may be related to good nanoparticles distribution and increased density of dislocation.

\section{References}

[1] Rout, P.K., Ghosh, M.M. and Ghosh, K.S., "Microstructural, mechanical and electrochemical behaviour of a $7017 \mathrm{Al}-\mathrm{Zn}-\mathrm{Mg}$ alloy of different tempers". Materials Characterization, vol. 104, pp. 49-60, 2015.

[2] Jiang, F., Zurob, H.S., Purdy, G.R. and Zhang, H., "Characterizing precipitate evolution of an Al$\mathrm{Zn}-\mathrm{Mg}-\mathrm{Cu}$-based commercial alloy during artificial aging and non-isothermal heat treatments by in situ electrical resistivity monitoring". Materials Characterization, vol. 117, pp. 47-56, 2016.

[3] Wang, Z., Li, H., Miao, F., Sun, W., Fang, B., Song, R. and Zheng, Z., "Improving the intergranular corrosion resistance of $\mathrm{Al}-\mathrm{Mg}-\mathrm{Si}-\mathrm{Cu}$ alloys without strength loss by a two-step aging treatment". Materials Science and Engineering: A, vol. 590, pp. 267-273, 2014.

[4] Cao, C., Zhang, D., Wang, X., Ma, Q., Zhuang, L. and Zhang, J., "Effects of Cu addition on the precipitation hardening response and intergranular corrosion of Al-5.2 Mg-2.0 Zn (wt.\%) alloy". Materials Characterization, vol. 122, pp. 177-182, 2016.

[5] Mamoon, A. A. Al-Jaafari, "Fatigue Behavior of Aluminum SiC Nano Composites Material with Different Reinforcement Ratio". In IOP Conference Series: Materials Science and Engineering, vol. 870, no. 1, pp. 012159, 2020. 
[6] Al-Alkawi, H.J.M., Al-Rasiaq, A.A. and Al-Jaafari, M.A.A., "Mechanical Properties of 7075 Aluminum Alloy Matrix/A12O3 Particles Reinforced Composites". Engineering and Technology Journal, vol. 35, no. (3 Part (A) Engineering), pp.239-245, 2017.

[7] Mohammed, H.J., Mahmood, I.A. and Al-Jaafari, M.A., "An Estimation Study on Fatigue transition Life of Nanocomposites Reinforced by AL2O3". Association of Arab Universities Journal of Engineering Sciences, vol. 25, no. 4, pp.185-202, 2018.

[8] Obaid, A.Y., Mahmood, I.A. and Abood, A.N., "Effects of friction stir processing on microstructural, hardness and damping characteristics of ferritic nodular cast iron". J. Eng. Sci. Technol, vol. 12, no. 1, pp. 229-240, 2017.

[9] Prashanth, K.G., Scudino, S., Klauss, H.J., Surreddi, K.B., Löber, L., Wang, Z., Chaubey, A.K., Kühn, U. and Eckert, J., "Microstructure and mechanical properties of Al-12Si produced by selective laser melting: Effect of heat treatment". Materials Science and Engineering: A, vol. 590, pp.153-160, 2014.

[10] Cao, C., Zhang, D., Zhuang, L. and Zhang, J., "Improved age-hardening response and altered precipitation behavior of $\mathrm{Al}-5.2 \mathrm{Mg}-0.45 \mathrm{Cu}-2.0 \mathrm{Zn}$ (wt\%) alloy with pre-aging treatment". Journal of Alloys and Compounds, vol. 691, pp. 40-43, 2017.

[11] Mohammed, A.A.H.J., Abd Al-Rasiaq, A. and Al-Jaafari, M.A., "Studying the effect of Different wt\% AL2O3 Nanoparticles of 2024Al Alloy/AL2O3 Composites on Mechanical Properties". AlKhwarizmi Engineering Journal, vol. 14, no. 2, pp. 147-153, 2018.

[12] Schubert, A. and Nestler, A., "Enhancement of Surface Integrity in Turning of Particle74 Reinforced Aluminium Matrix Composites by Tool Design". Procedia Engineering, vol. 19, pp. 300-305, 2011.

[13] Mishra, P., Das, D., Ukamanal, M., Routara, B. and Sahoo, A., "Multi-response optimization of process parameters using Taguchi method and grey relational analysis during turning AA $7075 / \mathrm{SiC}$ composite in dry and spray cooling environments". International Journal of Industrial Engineering Computations, vol. 6, no. 4, pp. 445-456, 2015.

[14] Das, D., Chakraborty, V., Nanda, B.K. and Routara, B.C., "Turning performance of Al 7075/SiCp MMC and multi-response optimization using WPCA and Taguchi approach". Materials Today: Proceedings, pp. 5, no. 2, pp. 6030-6037, 2018.

[15] S. Lu, J. Zhang, Z. Li, J. Zhang, X. Wang, A. Hartmaier, J. Xu, Y. Yan, T.Sun "Cutting pathdependent machinability of $\mathrm{SiCp} / \mathrm{Al}$ composite under multi-step ultra-precision diamond cutting". Chinese Journal of Aeronautics. vol. 34, no. 4, pp. 241-252, 2021.

[16] Liu, H.Z., Wang, S.J. and Zong, W.J., "Tool rake angle selection in micro-machining of 45 vol.\% $\mathrm{SiCp} / 2024 \mathrm{Al}$ based on its brittle-plastic properties". Journal of Manufacturing Processes, vol. 37, pp.556-562, 2019.

[17] Huang, S., Guo, L., Yang, H., Su, Y. and Xu, L., "Study on characteristics in high-speed milling $\mathrm{SiCp} / \mathrm{Al}$ composites with small particles and high volume fraction by adopting PCD cutters with different grain sizes". The International Journal of Advanced Manufacturing Technology, vol. 102, pp. 3563-3571, 2019.

[18] Mivehchi, H. and Varvani-Farahani, A., "The effect of temperature on fatigue strength and cumulative fatigue damage of FRP composites". Procedia engineering, vol. 2, no. 1, pp.20112020, 2010.

[19] Al-Alkawi Hussain Jasim Mohammed, Abthal Abd Al-Rasiaq \& Mamoon A. A. Al- Jaafari, "Effect of Cryogenic Treatments on Mechanical Properties of 7075 Aluminum Alloy Matrix/Al 203 Particles Reinforced Composites". International Journal of Engineering Research and Modern Education. vol. 2, no. 1, pp. 143-149, 2017.

[20] Muthukrishnan, N., Babu, T.M. and Ramanujam, R., "Fabrication and turning of $\mathrm{Al} / \mathrm{SiC} / \mathrm{B} 4 \mathrm{C}$ hybrid metal matrix composites optimization using desirability analysis". Journal of the Chinese Institute of Industrial Engineers, vol. 29, no. 8, pp.515-525, 2012.

[21] Rajasekaran, S., Udayashankar, N.K. and Nayak, J., 2011 . "T4 and T6 treatment of 6061 Al-15 vol.\% SiCP composite". ISRN Materials Science, 2012, Article ID 374719.

[22] Mhesssan, A.N., Hussein, H.A. and Alalkawi, H.M., 2012. "Effect of Temperature on Fatigue Transition life and Strength of Aluminum alloy". Engineering and Technology Journal, vol. 30, no. 6, pp.1058-1065, 2012. 